\title{
BENCHMARKING, SAFEGUARD CLAUSES AND VERIFICATION MECHANISMS - WHAT'S IN A NAME? RECENT DEVELOPMENTS IN PRE- AND POST- ACCESSION CONDITIONALITY AND COMPLIANCE WITH EU LAW
}

\begin{abstract}
Martina Spernbauer*
Summary: This article looks upon the most recent developments in the European Union's accession strategies, as from the start of accession negotiations. It first seeks to demonstrate that the pre-accession conditionality rationale of stabilising present and protecting future integration objectives underpins the so-called 'specific safeguard clauses' of the 2003 and 2005 Acts of Accession and the latter's cooperation and verification mechanism, accordingly referred to as post-accession conditionality tools. It then argues that this rationale, emphasised also in the imperative of maintaining the momentum of European integration of the Union's 'integration capacity', above all necessitates effective compliance with EU law, and thus full administrative and judicial capacity of (prospective) Member States. Indeed, the lynchpin of these new conditionality devices evokes putting them in the wider context of compliance mechanisms in the enlarged European Union. It thereby becomes apparent how conditionality has lead to a considerable empowerment of the European Commission which, when reaching into the post-accession phase, entails a problematic differentiation between the Member States. Conditionality methodology furthermore, and this is equally shown, has had an impact on the Commission's role as 'guardian of the treaty' within the overall system of ensuring compliance with EU law.
\end{abstract}

\section{Introduction}

A strategy of reinforcement by reward, commonly referred to as 'positive conditionality' underpins many of the European Union's foreignpolicy tools. While not a new concept in international relations, positive conditionality has only begun to take shape within the European agenda throughout the last two decades, ${ }^{1}$ and 'entails the linking, by a state or

\footnotetext{
* Martina Spernbauer, Doctoral Researcher, Department of Law, European University Institute, martina.spernbauer@eui.eu

1 In international relations, it is described as the use by a state, a regional or an international body of political, diplomatic and economic instruments and policies in order to influence the internal and external policies of a third state. It has been argued that the collapse
} 
international organisation, of benefits desired by another state to the fulfilment of certain conditions'. ${ }^{2}$ The extensive use of various incentives, ranging from development assistance to contractual and institutional ties, predicates the general transformative power of Europe upon third countries' policy decisions and legislative developments. Yet, the specificity of the nature and content of these incentives in a particular case, as well as the ways in which they are linked to the policy choice desired, which in turn depend on the specific relationship with the third country in question, make conditionality hard to describe in exhaustive and concrete terms.

While corresponding to a policy choice in external relations proper, the concept of conditionality stands out as the indispensable rationale of the European Union's pre-accession strategy. The setting of stringent membership conditions is designed to attain an objective that is essentially two-fold: on the one hand, the Copenhagen criteria and the continuous, 'objective' evaluation of candidate countries' progress based thereupon allow for the maintenance of the 'inclusive nature of the accession process' ${ }^{3}$ while nonetheless accommodating differentiation between the candidates based on 'individual merits'; on the other hand, accession conditionality seeks stabilisation of present, and protection of future, integration objectives. ${ }^{4}$

Consequently, the protection of the level of integration reached, which is measurable in quantity and quality through the acquis, does not allow for a renegotiation of membership conditions but requires a strategy whereby the aspiring members adopt and implement the acquis in its entirety. Indeed, an increasingly high degree of conditionality and its rigorous application are directly linked to expanding membership obligations. Fulfilling the obligations of membership in an 'ever closer Union' is, in general, increasingly difficult - for current and future member states alike.

In legal academic literature, the ramifications of the European Union's fifth enlargement are frequently examined in terms of the processes and constitutional implications of approximation to EU law within the acceding states. This paper proposes a different focus. It is an endeavour

of the USSR marked a turning point as during the Cold War what was generally referred to as 'linkage' was used mostly as a policy tool in the context of the bipolar confrontation. Cf E Lannon, E Haenebalcke and K Inglis, 'The Many Faces of EU Conditionality in Pan-EuroMediterranean Relations' in E Lannon and M Maresceau (eds), The EU's Enlargement and Mediterranean Strategies: A Comparative Analysis (Palgrave, London 2001).

2 K Smith, 'The Evolution and Application of EU Membership Conditionality' in M Cremona, The Enlargement of the European Union (OUP, Oxford 2003) 105, 108.

3 December 1999 Helsinki European Council Conclusions. In the aftermath of the Kosovo crisis, Turkey was granted 'candidate status', while the start of accession negotiations with the 'second wave' of the Central and Eastern European Countries, namely Slovakia, Latvia, Lithuania, Bulgaria and Romania as well as Malta was decided.

4 Cf Smith (n 2) 106. 
to determine the possible impact of accession conditionality upon the European Union itself, arguing that its very rationale of protecting the achievements and maintaining the momentum of European integration is put at risk by the use of conditionality in the way the latter has evolved, and by demonstrating that its new forms increasingly blur the borderline between members and non-members. The important underlying premise is that, with the European model of integration primarily following an approach of integration through law, maintaining the 'momentum of integration' depends on the effective enforcement of European Union law. The latter in turn requires efficient cooperation of national courts and administrative authorities.

The objective thus referred to lends itself to a structure that is essentially two-fold. It seems appropriate to trace, in a first part, the most recent developments with regard to the European Union's concept of conditionality. Conditionality has indeed undergone a somewhat threedimensional evolution. In the first place, there is now an extensive use of membership conditionality with respect to third countries which have not yet applied for membership, let alone started accession negotiations. This is particularly the case in the framework of the Stabilisation and Association Process. ${ }^{5}$ The countries of the Western Balkans, merely having been granted potential candidate status, ${ }^{6}$ are subject to European Partnerships $^{7}$ - and consequently are working towards compliance with political and economic membership criteria according to a pre-determined agenda, even in the absence of contractual ties. For eventual establishment of the latter, the Union insists that these countries make 'credible headway' in complying with the political Copenhagen criterion. ${ }^{8}$ Subsequently, a satisfactory track-record in implementing Stabilisation and Association Agreement obligations is a pre-requisite for the EU to consider an application for membership. While this kind of pre-pre-acces-

\footnotetext{
5 Cf 'Conclusions on the Principle of Conditionality Governing the Development of the European Union's Relations with Certain Countries of South-East Europe' Bulletin EU 41997, establishing a 'graduated approach'.

6 Cf 2002 Feira European Council Conclusions. In a joint declaration issued after the Thessaloniki EU-Western Balkans Summit, they were declared an 'integral part of unified Europe.' 'Declaration of the Thessaloniki EU-Western Balkans Summit' (21 June 2003) EU Doc 10229/03, 5.

7 Based on Council Regulation 533/2004 on the establishment of European partnerships in the framework of the stabilisation and association process [2004] OJ L 86/1. Unlike Council Regulation 622/98, which provided the basis for the CEEC Accession Partnerships and was adopted by virtue of Art 308 ECT, this regulation finds its legal basis in Art 181a (2) ECT. Cf also K Inglis, 'EU Enlargement - Membership Conditions applied to Future and Potential Member States' in K Inglis and A Ott, The Constitution for Europe and an Enlarging Union: Unity in Diversity? (Europa Law Publishing, Groningen 2005).

8 One cannot omit to mention at this point that the benchmarks used for opening negotiations on a Stabilisation and Association Agreement are the same as those identified in the Commission's positive opinion for opening accession negotiations in its Agenda 2000 country opinions. Cf Inglis (n 7).
} 
sion conditionality is undoubtedly worth looking at, the confines of the present contribution do not allow for its in-depth analysis. It is thus proposed to limited the analytical timeframe to the period after the start of accession negotiations. The second evolutionary dimension with respect to the use of conditionality concerns the way in which conditionality increasingly operates more openly throughout the pre-accession process: a tool of 'benchmarking', introduced in the context of the adoption of the negotiating frameworks for Croatia and Turkey, is applied for the opening and closure of each individual negotiating chapter. Furthermore, a new chapter 'Judiciary and Fundamental Rights' allows for issues which were previously addressed under the political Copenhagen criterion and whose respect was thus a pre-requisite for the start of negotiations, to be decisive for progress in negotiations as such. Thirdly, conditionality now reaches into the post-accession period by virtue of specific safeguard clauses provided for in the Acts of Accession of 2003 and 2005, with the latter being reinforced by 'cooperation and verification mechanisms in the area of judicial reform and the fight against organised crime and corruption', endorsed by the Council in October 2006.

In a second part, the consequences of these new dimensions of accession conditionality, in particular within the overall system of ensuring compliance with EU law, will be reflected upon. Therein, it will be demonstrated how conditionality - in procedural terms - has led to a considerable empowerment of the European Commission. Indeed, the 'guardian of the Treaties' no longer merely has a central role in ensuring the enforcement of Community law, it also has acquired a pivotal position throughout the entire pre- accession process that increasingly - through these new mechanisms - reaches into the post-accession phase. In addition, considering that the lynchpin of these new devices is found in the institutional aspects of 'the ability to take on the obligations of membership', merely taken to a different stage in the course of the accession process, a closer look will be given to the imperative of 'full administrative and judicial capacity' of prospective member states.

\section{Membership conditionality in new disguise: benchmarking, safeguard provisions, and the cooperation and verification mechanism}

Within the framework of analysis set out above, it is proposed to consider the new developments in EU membership conditionality chronologically in the context of accession negotiations. The introduction of the concept of 'benchmarking' will be examined first, then the new so-called 'specific safeguard clauses' introduced in the 2003 Act of Accession ${ }^{9}$ and

9 'Act concerning the conditions of accession of the Czech Republic, the Republic of Estonia, the Republic of Cyprus, the Republic of Latvia, the Republic of Lithuania, the Republic 
the Protocol concerning the conditions and arrangements for admission of the Republic of Bulgaria and Romania ${ }^{10}$ (henceforth 2005 Act of Accession) will be examined, before attempting to conceptualise the cooperation and verification mechanisms which entered into force on 1 January 2007.

First, a few preliminary lines on what is rightly considered the fundamental basis and lasting reference point of the current pre-accession strategies, the 1993 Copenhagen criteria, are appropriate, as the necessity for their "permanent adaptation"11 and their progressive procedural and substantive clarification illustrates the inherently evolving nature of EU membership conditionality, which is functional to its very purpose. Naturally, what follows will necessarily be highly selective, based upon their relevance for the current contribution. ${ }^{12}$

After declaring that the 'associated countries in Central and Eastern Europe that so desire shall become members of the European Union', the European Council established the well-known conditions, encompassing political, economic, 'acquis' and 'absorption capacity' criteria. ${ }^{13} \mathrm{Be}-$ ing vague in substance, the conclusions were similarly so in procedural terms, merely stating that the 'European Council [would] continue to follow closely the progress in each associated country towards fulfilling the

of Hungary, the Republic of Malta, the Republic of Poland, the Republic of Slovenia and the Slovak Republic and the adjustments to the Treaties on which the European Union is founded' [2003] OJ L236/33.

10 'Protocol concerning the conditions and arrangements for admission of the Republic of Bulgaria and Romania to the European Union' [2005] OJ L157/11.

11 M Maresceau, 'The EU pre-accession strategies: a political and legal analysis' in M Maresceau and E Lannon (eds), The EU's Enlargement and Mediterranean Strategies: A Comparative Analysis (Palgrave, London 2001).

12 A great number of these, in particular with reference to the Western Balkan countries, will thus have to be left out. For further reference, see eg Inglis (n 7) $242 \mathrm{ff}$.

13 Under the Copenhagen criteria, membership requires that the candidate country ensures:

1. the stability of institutions guaranteeing democracy, the rule of law, human rights and respect for and protection of minorities: political criteria.

2. the existence of a functional market economy as well as the capacity to cope with competitive pressure and market forces within the Union: economic criteria.

3. the ability to take on the obligations of membership including adherence to the aims of political, economic and monetary union: acquis criterion. Cited by the Commission in European Commission, 'Towards the Enlarged Union: Strategy Paper and Report of the European Commission on the progress towards accession by each of the candidate countries' COM (2002) 700 final, 9 October 2002. Therein a fourth criterion is not mentioned. However, the Copenhagen European Council in addition referred, as an 'important consideration in the general interest of both the Union and the candidate countries', to the EU's capacity to absorb new members while maintaining the momentum of European integration. A report by the Council to the Essen European Council in December 1994, on the development of an accession strategy, also refers in this context to 'respecting [the EU's] internal cohesion and its fundamental principles.' Cited in M Cremona, 'EU enlargement: solidarity and conditionality' (2005) 30 ELR 3, 16. 
conditions of accession to the Union and draw the appropriate conclusions'. Subsequently, they have undergone progressive legalisation, 'institutionalisation' ${ }^{14}$ and even constitutionalisation. Indeed, by the way in which they have been prescribed by the highest political authority of the European Union and institutionalised by the subsequent pre-accession and enhanced pre-accession strategies, they have become quasi-legal ${ }^{15}$, or at least legally enforceable ${ }^{16}$ requirements. In procedural terms, primary law provided from the onset for a certain presetting: Article 49 TEU (and its predecessor Article 237 EEC). ${ }^{17}$ In terms of substance, however, and notwithstanding the fact that the same core fragments can also be traced back through previous enlargements, ${ }^{18}$ the Copenhagen European Council has effectively supplemented Article 49 TEU by, inter alia, declaring that 'accession will take place as soon as an associated country is able to assume the obligations of membership by satisfying the economic and political conditions required'. By now, they have acquired a quasiconstitutional status, ${ }^{19}$ which is confirmed by the fact that all subsequent applications' for membership have been made subject to these criteria. ${ }^{20}$

Considering the fundamental importance of the Copenhagen conditions, their vagueness and continuously changing substance might at first glance be astonishing. Yet, their evolving nature both in terms of substance and procedure is in fact functional to their very purpose. As pointed out, they are formulated and reformulated in order to secure present and future integration achievements. In other words, membership conditionality not only relates to the ability of prospective members to cope with the demands of membership, but also concerns the destabilising effect of the presence of new members who do not (yet) share the po-

14 C Hillion, 'Enlargement of the European Union: A Legal Analysis' in A Arnull and D Wincott (eds), Accountability and Legitimacy in the European Union (OUP, Oxford 2002) 408.

15 Ibid 409.

16 See also below on Accession Partnerships.

17 In 1978, the Court was asked to give a preliminary ruling on the 'conditions of admission and the adjustments to the Treaties' and considered that Article 237 EEC laid down 'a precise procedure encompassed within well-defined limits for the admission of new Member States, during which the conditions of accession are to be drawn up by the authorities indicated in the article itself. Thus the legal conditions for such accession remain to be defined in the context of that procedure without it being possible to determine the content judicially in advance.' Case 93/78 Mattheus $v$ Doego [1978] ECR 2230 paras 7-8.

18 For a detailed account of the history, the meaning and use of the political criteria, see D Kochenov, 'Behind the Copenhagen façade. The meaning and structure of the Copenhagen political criterion of democracy and the rule of law' (2004) 8 European Integration Online Papers 10; for a more general appreciation, see also Smith (n 2)109ff.

19 This has not been changed by the introduction of Article 6 (1) TEU and reference in Article 49 TEU thereto.

20 The December 1999 Helsinki European Council, for instance, declared that Turkey was 'a candidate State destined to join the EU on the basis of the same criteria as applied to the other candidate States'. 
litical, economic and legal capacity of existing members. ${ }^{21}$ The conditions' progressive evolution and supplementation can primarily be ascribed to the ongoing development of the European Union, but on the other hand illustrate a process which is responsive to the specificity of the aspiring member state and other parameters surrounding its application. It has however always been inconceivable that the threshold of membership should be lowered with the accession of new members, illustrated, inter alia, in the notion of an 'ever closer Union among the peoples of Europe.' An early illustration of this may be found in the Preamble of the 1972 Accession Treaty, according to which the parties were 'determined, in the spirit of the Treaties, to construct an ever closer union among the peoples of Europe on the foundation already laid'. Therefore, by reason of their future status as member states, the acceding states have always been under an obligation, although not mentioned in Article 49 TEU to adopt the entire acquis communautaire. ${ }^{22}$ This obligation has thus from the onset been ${ }^{23}$ and continues to be one of the key accession principles. Conversely, the understanding of the "conditions of admission and the adjustments to the Treaties' to be negotiated by the Parties, has indeed been fairly restrictive. Only in exceptional cases has 'adjustment' been envisaged as a re-negotiation of the acquis with the applicant state. ${ }^{24}$

Turning to a few examples illustrating this 'permanent adaptation' then, one needs to begin with the emergence as primus inter pares of the first, political, Copenhagen criterion. In the aftermath of the Kosovo crisis, ${ }^{25}$ its fulfilment has become the pre-requisite for the opening of accession negotiations. While the European Union's initial approach was an exclusive one, requiring the fulfilment of all conditions - at least in the medium term - in order for accession negotiations to start, ${ }^{26}$ the December 1999 Helsinki European Council has moved to a more inclusive

21 Cf Cremona (n 13) 16.

22 On the meaning, use and evolution of this term, see $\mathrm{C}$ Delcourt, 'The acquis communautaire: Has the concept had its day?' (2001) 38 CML Rev 829.

23 Cf F Hoffmeister, 'Earlier enlargements' in A Ott and K Inglis (eds), Handbook on European Enlargement (TMC Asser Press, The Hague 2003) 87, at 97.

24 For examples, see Hillion (n 14) 406.

25 Cf Cremona (n 13) 16. Hillion in this context refers to the changing function of the criteria. Cf C Hillion, 'The Copenhagen Criteria and their Progeny' in C Hillion (ed), EU Enlargement - a Legal Approach (Hart Publishing, Portland 2004).

26 Demonstrated by the 1997 December European Council. This, however, should not be considered too categorical as the fulfilment of the non-political criteria were assessed in a more prospective, forward-looking way, and Estonia, Hungary, Poland, Slovenia and the Czech Republic were considered to satisfy those conditions only in the medium term. The multi-layered conditionality that is employed in the framework of the Stabilisation and Association Process, is reminiscent of the evolution of the Copenhagen political criteria into an 'admissibility' condition. 
approach, ${ }^{27}$ excluding only Turkey explicitly on the basis of the political criterion. This however has not meant that an acceding state, ie a candidate state having started accession negotiations, has a perfect record in all aspects of the political criterion. Recently, this approach has been readjusted by the introduction of a new negotiating chapter on 'Judiciary and Fundamental Rights' (Chapter 23) which allows for these issues to be addressed throughout the accession negotiations. Arguably therefore, the threshold for the beginning of accession negotiations has been potentially lowered, in contrast to the one for membership. On the other hand, it could be possible that the level set for the opening of negotiations has remained the same while the standard set for the conclusion of negotiations has been and/or will be raised. The precise way in which this chapter will be used remains to be seen.

Secondly, the December 1995 Madrid European Council importantly qualified the requirement of the 'ability to take on the obligations of membership' by stressing that the applicant countries should 'adjust their administrative structures'. Subsequent European Councils have confirmed and elaborated this, sometimes considered additional, ${ }^{28}$ institutional requirement. With the conclusion of accession negotiations approaching, the parameters of effective and accountable administrative structures as well as an impartial and efficient judiciary, acknowledged to be crucial for the effective implementation of the acquis, have progressively ${ }^{29}$ moved up the agenda, eventually becoming a prime priority. While the imperative of adequate administrative and judicial structures and its implications will be considered below, it is important to emphasise that it did not explicitly figure among the initial membership conditions.

Finally, it seems appropriate to address briefly the issue of 'absorption capacity' in this context. It is recalled that the 'Union's ability to integrate new members' has already figured among the original 1993 Copenhagen criteria. Its spectacular emergence at the highest political level in autumn 2005 in the context of whether or not to open accession negotiations with Turkey (and Croatia) cannot mask its pressure on the

${ }^{27}$ Cf Hillion (n 14) 412. It is the present's author submission that this is a clear indication that enlargement strategy was and continues to be a security strategy aiming at the political and economic stabilisation of the entire continent.

28 For instance, P Nicolaides, 'Preparing for Accession to the European Union: How to Establish Capacity for Effective and Credible Application of EU Rules' in M Cremona, The Enlargement of the European Union (OUP, Oxford 2003) 43.

29 This has to be seen in close connection with the growing awareness that the acquis not only needed to be adopted but effectively implemented and enforced. The $2001 \mathrm{Commission}$ Strategy Paper for instance, upheld by the European Council of December 2001, underlined that progress in the negotiations was based on convincing progress in adopting, implementing and enforcing the acquis. The 2002 Seville European Council reiterated in forceful terms that 'the candidate countries must take all necessary measures to bring their administrative and judicial capacity up to the required level.' 
ongoing attempts at institutional reform. Indeed, the likelihood that the fourth Copenhagen criterion might be used in future accession negotiations to slow down the pace of negotiations or maybe even to postpone a candidate's accession has already been argued. ${ }^{30}$

Having thus recalled the underpinnings and some specificities of the process of accession to the European Union by revisiting aspects of the inherently flexible and evolving nature of the Copenhagen criteria, recent developments in concrete, primarily procedural terms of the concept of accession conditionality will be considered by following, as pointed out, a 'chronological' order.

\section{The concept of 'benchmarking'}

'Benchmarking' is in essence an evaluation and assessment instrument with the help of detailed, ex-ante, performance indicators. It was added to the European Union's tool box when the European Commission decided in 1996 to apply and utilise it as a method to evaluate and compare the efficiency and performance of the national labour markets of individual member states. In the context of the Lisbon Strategy in particular, in which the use of an 'open method of coordination' for evaluating the performance of the Member States based on 'benchmarking' has emerged, the Commission is committed to reinforcing the regular Scoreboards with indicators of the performance of the Member States. ${ }^{31}$ With the adoption of the Wider Europe Policy in March 2003, which developed into the European Neighbourhood Policy, benchmarking was also incorporated in the EU's foreign policy. In the broadest sense, benchmarking is a system that aims at comparing in a systematic manner organisational processes and/ or performances with the objective of improving these processes and thus creating new (and higher) standards. Theoretically, all benchmarking models require ex-ante decisions as regards measurement methods, the units to be measured, the appropriate indicators, and detailed and transparent timetables that determine the exact time horizon that all actors involved need to comply with. The concept of benchmarking aims at identifying concrete possibilities for improvement by comparing pre-defined indicators. Hence, its global objective is to facilitate decisions even if the information may sometimes be characterised by uncertainty. Ideally though, the degree of uncertainty is low, not least due to the utilisation of peer reviews and monitoring, and in a final stage, a follow-up monitoring of progress. ${ }^{32}$

30 Cf Inglis (n 7) 230.

31 Cf Nicolaides (n 30) 53.

32 Thanks to Raffaella A Del Sarto, Jean Monnet Fellow, European University Institute, for invaluable input on this point. See also R Del Sarto, T Schumacher, E Lannon and A Driss, Benchmarking Democratic Development in the Euro-Mediterranean Area: Conceptualising Ends, Means, and Strategies (EuroMeSCO, 2006) (forthcoming). 
In the enlargement context, two fairly recent policy developments may be considered as de facto precursors to the introduction of "benchmarking' proper. In the first place, the six rather specific legislative acts that were mentioned in the December 2004 European Council Conclusions should be mentioned. Their adoption and implementation by Turkey was required in order for it to eventually start accession negotiations. Secondly, the Roadmaps for Bulgaria and Romania ${ }^{33}$ provided clear performance indicators (the term 'benchmark' was not used) against which commitments made in the course of negotiations were intended to be monitored. These roadmaps aimed at supporting the two countries' efforts to meet the remaining criteria for membership by identifying the tasks ahead in the form of 'key steps', split into short term, medium term, and long-term steps, for each of the acquis negotiating chapters. The parameters included both alignment of legislation and development of administrative and judicial capacity. With regard to these 'predecessors', it readily becomes apparent that in the context of accession conditionality, 'benchmarking' essentially corresponds to an attempt at further 'detailing' the process, in terms both of substance and of procedure.

For the remaining candidates, some of which have started accession negotiations, the Commission proposed the adoption of benchmarks, presented as a 'new tool introduced as a result of lessons learnt from the fifth enlargement, to improve the quality of accession negotiations, by providing incentives for the candidate countries to undertake necessary reforms at an early stage. ${ }^{34}$ They are linked to key elements of each $a c^{-}$ quis chapter and apply throughout such a chapter's 'lifecycle'. The procedure is as follows: after a chapter has been screened, the Member States decide, upon a Commission recommendation, on whether the chapter can be opened for negotiation, or alternatively on the benchmarks to be met by the candidate country before its opening. Upon opening negotiations, the Union tables its common position which ideally includes benchmarks that have to be met in order to provisionally close the chapter. In terms of substance, opening benchmarks concern 'key preparatory steps for future alignment, and the fulfilment of contractual obligations that mirror acquis requirements', whereas closing benchmarks 'primarily concern legislative measures, administrative and judicial bodies, and a track record of implementation of the acquis.' Of particular interest is the possibility for the Union-side to, upon proposal from the Commission, suspend negotiations of a chapter for which the candidate country no

33 European Commission, 'Roadmaps for Bulgaria and Romania' COM (2002) 624 final, 13 November 2002.

34 European Commission, 'Enlargement Strategy and Main Challenges 2006-2007, including annexed special report on the EU's capacity to integrate new members' COM (2006) 649 final, 8 November 2006, 6. 
longer fulfils the opening benchmarks. Likewise, and following the same procedure, a provisionally closed chapter may be re-opened in the case of a country no longer fulfilling the closing benchmarks. By way of example, the outcome of screening on chapter 24, ie Justice, Freedom, and Security for Croatia can be mentioned. While Croatia was not considered sufficiently prepared for negotiations on this chapter, the Member States agreed $^{35}$ on the adoption of an updated Integrated Border Management Action Plan, ${ }^{36}$ as an opening benchmark.

It has been argued that the "mutation of the accession conditions into more tangible legal benchmarks in combination with the increasing institutionalisation of the process, raises the level of expectation of 'complying' applicants. ${ }^{37}$ This can be fully subscribed to, and a fortiori will be the case once the practice of detailed benchmarking has become the norm. However, the further submission that the criteria's embryonic constitutional character increasingly commits the Union, ${ }^{38}$ does not take sufficient account of the existence of the fourth Copenhagen criterion. Not only is it true that upon fulfilment of all 'objective' conditions by a candidate, the latter does not acquire a right to accede; the existence of the 'absorption capacity condition' will always add a necessarily subjective and thus inherently elusive parameter to the process. Furthermore, it is submitted that this process, based on a distinction between opening and closing benchmarks, leads to a particular classification of the acquis communautaire which entails a certain degree of hierarchy. A hierarchy that might, and arguably in many instances will, be different from the concepts of primary and secondary law sources, or any differentiation that is made in terms of importance of certain parts of the acquis over others. ${ }^{39}$ Any possible concerns over this however, are alleviated by a fundamental negotiation principle that also applies in an accession context: 'Nothing is agreed until everything is agreed'.

35 Council Secretariat, Document 11667/06 (17 July 2006).

36 Ibid. The Action Plan included 'concrete actions for both the land border and the blue border with targets, realistic deadlines, responsible authorities and an estimated budget for each of the actions which require substantial investments. This plan should cover issues related to enhancing inter-agency cooperation, legislative alignment and institution-building and should include increasing the number of border guards, enhancing training efforts and improving coordination between the involved services.'

37 Hillion (n 14) 412.

38 Ibid.

39 Partly on the basis of Opinions $1 / 91$ and $1 / 92$, a distinction has been made, for instance, between a 'fundamental acquis' and other types of the acquis, with the former depicting 'the internal constitution of the Community' and thus fundamental institutional and ethical rules; cf Delcourt (n 22) 841-848. 


\section{The safeguard mechanisms in the most recent Acts of Accession}

Under the title 'temporary provisions' 40 of the most recent Acts of Accession, appear - alongside a general economic safeguard clause ${ }^{41}$ two so-called 'specific safeguard clauses'. They are, when analysed in a substantial way, often seen as part of a general discussion of the Act of Accession $2003^{42}$ and or of $2005^{43}$ but are not generally presented in the context of pre-accession conditionality. ${ }^{44}$ This paper, however, seeks to demonstrate that they are essentially conditionality tools, encapsulating the spirit and methodology as well as the fundamental function of accession conditionality, as instrumentalised by the pre-accession strategy. The 'Internal Market' as well as the 'Justice and Home Affairs' ${ }^{15}$ safeguard clauses $^{46}$ represent a form of 'post-accession' conditionality, ${ }^{47}$ reflecting

\footnotetext{
40 Temporary provisions in general, provide for the possibility to restrict the application of the acquis or to adopt protective measures, with both being subject to procedural and substantive conditions.

41 Article 37 and Article 36 of the 2003 Act of Accession and 2005 Act of Accession, respectively. The clause is not a novelty and has, albeit with a shorter period of application (one year instead of three), already been included in the Act of Accession for Austria, Finland and Sweden (Article 152).

42 Cf C Hillion, 'The European Union is dead. Long live the European Union. A commentary on the Treaty of Accession 2003' (2004) 29 ELR 583; K Inglis, 'The Union's fifth Accession Treaty: New means to make enlargement possible' (2004) 41 CML Rev 937; E Lannon, 'Le Traité d'adhésion d'Athènes' (2003) 17 Cahiers du droit européen; with the exception of Leardini and Isak, who exclusively focus on the Internal Market safeguard clause: P Leardini, 'Une nouveauté dans l'Acte d'adhésion des dix nouveaux Etats membres de l'Union européenne: la clause de sauvegarde 'Marché intérieur' (2004) Revue du Droit de l'Union Européenne 53; H Isak, 'Binnenmarkt und EU-Erweiterung' in M Karollus, H Köck and S Stadlmeier, Gegenwärtiger Stand und zukünftige Entwicklungen des EU-Binnenmarktes (Trauner Verlag, Linz 2006) 43.

43 Cf A Lazowski, 'And then they were twenty-seven... A legal appraisal of the sixth accession treaty' (2007) 44 CML Rev 401.

44 For a notable exception, see Cremona (n 13) and, to a certain extent, Inglis (n 42).

45 It is submitted that the notion 'Justice and Home Affairs' in the present contribution is used interchangeably with 'The Area of Freedom, Security and Justice'.

46 The provisions in the 2005 Act of Accession in essence duplicate their predecessors. Article 37 of the 2005 Act of Accession corresponds to Article 38 of the 2003 Act of Accession. Conversely, Article 38 of the former duplicates Article 39 of the latter. The provisions of the 2005 Act of Accession deviate only by way of integrating the language of the Constitutional Treaty. After proposal by the European Commission in September 2002, the respective Council Working Group considered the provisions, before the texts were adopted by the Council in October 2002 tel quel, with the only changes made in terms of prolonging the invocation period from two to three years. Cf Leardini (n 42) 58.

47 In the affirmative, even though she does not use the expression 'post-accession' conditionality, see Inglis (n 42). According to this author's view, the 'current' enlargement presents enormous challenges to the function of the Union, which demands a high degree of mutual trust between Member States and explains the introduction of the new safeguard measures. Leardini (n 42) considers the extremely diverse socio-economic and judicial situations in the acceding states and above all the very limited number of transitional arrangements, as the main reasons for introducing the Internal Market safeguard clause.
} 
the need to ensure that the new member states keep up their momentum in approximation to and compliance with the internal market and JHA acquis. ${ }^{48}$ Two arguments, closely related, support this argumentation.

First, the wording of the safeguard clauses implicitly reflects their conditionality nature. This applies in particular to the expression 'commitments undertaken in the context of the accession negotiations', used in the Internal Market safeguard clauses. ${ }^{49}$ Some commentators ${ }^{50}$ have criticized the elusiveness of this term, whereas it is submitted here that this expression perfectly encapsulates the intended function of this type of post-accession conditionality. The term had been chosen precisely in order to ensure the European Union's, or indeed the Commission's firm grip over ongoing reforms in the acceding and new Member States. It deliberately goes beyond the suggestion of a unilateral declaration by six new Member States, namely that it 'only covers the obligations that are arising from the original Treaties applicable to (the respective new Member States), under the conditions laid down in the Act of Accession, and the obligations defined in this Act. ${ }^{51}$ It is argued that, first, the expression 'commitments undertaken in the context of the accession negotiations' relates to the 'pace of accession negotiations' 52 and that, second, it is mostly by reason of the continuous lack of full and adequate administrative and judicial capacity that such a wording was chosen. ${ }^{53}$ Although there is no acquis as to what may be considered 'adequate administrative structures' or 'efficient judiciary', the pre-accession instruments allowed

48 Cf Inglis (n 42) 953.

49 Articles 38 and 37 of the 2003 and 2005 Acts of Accession, respectively.

50 Cremona for instance asks what other commitments might be intended than Community law obligations in the ordinary sense; cf Cremona (n 13) 20. Hillion on the other hand claims that all essential commitments undertaken during the accession negotiations should have been included in the Treaty and thus wonders why reference is not directly made to the Treaty of Accession itself; cf Hillion (n 42) 603. Leardini finally calls for a pragmatic approach to interpret this expression and lists a number of possible examples, such as going-beyond production quota, non-elimination of state aids contrary to Community law, insufficient supervision of financial services, or the preservation of an inadequate level of education in the health care sector that would justify suspension of the free movement provisions; cf Leardini (n 42) 53.

51 Declaration No 22, 'Joint Declaration by the Czech Republic, the Republic of Estonia, the Republic of Lithuania, the Republic of Poland, the Republic of Slovenia and the Slovak Republic on Article 38 of the Act of Accession' [2003] OJ L236/33, 978.

52 Hillion ( $\mathrm{n}$ 42) 603. This author merely considers this as a possibility. He further points to the fact that the provisional closure of the chapters was made conditional on the Union confidence in the credibility of the 'commitments made by the candidates'.

53 In its 2003 Comprehensive Monitoring Report, for instance, the Commission warned using the safeguard clauses to address failures in the administrative capacity of several acceding states, to apply the rules on mutual recognition of professional qualifications or social security provisions. Cf European Commission, 'Comprehensive Monitoring Report of the European Commission on the state of preparedness for EU membership' COM (2003) 675 final, 5 November 2003. 
for guidance and monitoring the required and enormous reform efforts of the candidate states with respect to their public service sectors and the judiciary, and ultimately the effective implementation and enforcement of the acquis. The only possibility for ensuring continuity in this respect was to use a wording in the 'specific safeguard clauses' that would provide an explicit legal basis to tackle failures in meeting pre-accession commitments in the crucial domain of administrative and judicial capacity. Indeed, it was in this context that the Internal Market safeguard clause was invoked by the Commission shortly before the accession of Bulgaria - at the time of writing the only instance of its use. Due to serious shortcomings in aviation safety, the Commission adopted safeguard measures in the form of a Commission regulation on the basis of Articles 4(3) and 37 of the 2005 Act of Accession. ${ }^{54}$ Under its provisions, airworthiness and maintenance certificates issued by the Bulgarian authorities are not recognized in the EU (Article 1). Moreover, air carriers with Bulgarian licences are not granted unlimited access to the EU aviation market, as they do not qualify as 'Community air carriers'. These are considered appropriate measures by the Commission, resulting from the lack of administrative capacity of the Bulgarian Civil Aviation Authorities to fulfil the required safety oversight duties.

Second, the safeguard clauses are, just as conditionality instruments in general, of an essentially protective nature, envisaging the maintenance of the achieved level of European integration. The provisions in the Acts of Accession should be considered as a direct continuation of pre-accession monitoring. As a result of the Commission's often articulated intention to continuously monitor the implementation of the commitments and obligations taken on by the acceding (sic) states, the safeguard clauses were worded so as to allow for their invocation also before accession, in the case of which the adopted measures would enter into force as of the date of accession. The reach of pre-accession efforts into the post-accession phase in domains considered to be crucial is also illustrated by the introduction of a 'special transition facility for institution building, ${ }^{55}$ in order to further support administrative and judicial capacity building. Furthermore, the Commission, as 'guardian of the Treaties', perceives and presents these provisions as 'precautionary measures' which supplement existing safeguard mechanisms, ${ }^{56}$ peer pressure, an-

54 Commission Regulation (EC) 1962/2006 of 21 December 2006 on application of Art 37 of the Act of Accession of Bulgaria to the European Union [2006] OJ L408/8.

55 European Commission, 'Towards the Enlarged Union: Strategy Paper and Report of the European Commission on the progress towards accession by each of the candidate countries' COM (2002) 700 final, 9 October 2002, 27.

56 The Internal Market Safeguard clauses themselves give precedence to existing sectoral safeguard mechanisms, such as Article 30 ECT or specific safeguard clauses that may have been introduced into secondary legislation by virtue of Art 95 ECT. The latter, for instance, 
nual reporting on implementation of Community law ${ }^{57}$ or infringement proceedings. ${ }^{58}$ Arguably therefore, these provisions do not directly relate to the enforcement of the aquis, in the sense of compelling compliance with an obligation ${ }^{59}$, but merely aim at avoiding all risks of non-application of the acquis by the new Member States, and thus reassuring the old Member States, ${ }^{60}$ should a situation arise, "which may have serious non-economic consequences such as for the protection of health or life of humans, animals or plants, protection of intellectual property or general reasons of public policy as defined in Article 30 ECT, ${ }^{61}$ areas also highlighted in the comprehensive Monitoring Reports.

\section{The cooperation and verification mechanism}

The third development of the European Union's accession conditionality, is the so-called 'cooperation and verification mechanism' that as much as the two provisions just discussed is a form of post-accession conditionality. In its Monitoring Report on the state of preparedness for EU membership of Bulgaria and Romania from September 2006, ${ }^{62}$ the European Commission confirmed these countries' 'capacity to apply EU principles and legislation from 1 January 2007.' In the very same report however, it was obliged to highlight a number of domains where immediate action or further efforts were required: for Bulgaria, inter alia, the justice system (transparency and efficiency of judicial processes; adoption of the procedural code and the judicial system act), the fight against corruption, police cooperation and the fight against organised crime, and the integrated administrative control system for agriculture (TACS); for Romania, the justice system (consistent interpretation and application of the law in all courts), the fight against corruption, paying agencies and

provide for emergency measures to be taken by the Commission or a Member States where a serious risk is posed to human health, animal health or the environment. By way of example, Articles 53 and 54 of Regulation 178/2002 laying down the general principles and requirements of food law, establishing the European Food Safety Authority and laying down procedures in matters of food safety (OJ L31/1) may be mentioned.

57 The comprehensive Monitoring Reports, for instance, are presented as a precursor of the Annual Report on the Monitoring of the Application of Community law, issued regularly by the Commission for all Member States. Cf European Commission (n 55) 25.

58 Commissioner Verheugen, in a speech in November 2002 before the Assemblée nationale française, stated that the safeguard provisions would 'certainly not [be used] against infringements of the Treaties.' Translated from Lannon (n 42).

59 Cf S Andersen, 'The Functional Overlap of Enforcement and Implementation Tools' in this issue.

60 Cf Lannon (n 42) 65.

61 European Commission (n 55) 25.

62 Cf European Commission, 'Monitoring Report on the state of preparedness for EU membership of Bulgaria and Romania' COM (2006) 549 final, 26 September 2006 
interconnectivity of tax systems. Clearly, the justice system and various levels of public administration, as well as the fight against corruption constitute the core of the concerns identified by the Commission. Bearing thus in mind the shortcomings in fulfilling accession commitments in this area, the Commission has decided to introduce a 'scrutiny mechanism adding a preliminary phase' 63 to the one-stage procedure for invoking the safeguard clauses, without however precluding an immediate application of the latter, should it prove necessary. ${ }^{64}$

By way of Commission decisions for Bulgaria and Romania respectively, that entered into force on these countries' date of accession, the Commission indorses the specific benchmarks already established in its September 2006 Monitoring Report as it considers that the remaining issues in the accountability and efficiency of the judicial system and law enforcement bodies warrant the establishment of a mechanism for cooperation and verification of the progress of Bulgaria/Romania to address specific benchmarks in the areas of judicial reform and the fight against corruption (and organised crime in the case of Bulgaria). ${ }^{65}$ The mechanism thus applies to selected types of accession commitments only. Based on Articles 37 and 38 of the 2005 Act of Accession, but also the EC Treaty and the Treaty establishing the European Union, as well as the Treaty of Accession and Article 4 (3) thereof, ${ }^{66}$ the decisions also provide for the possibility to amend the benchmarks listed in the annexes, as well as for their repeal when all the benchmarks have been fulfilled. Under their provisions, the newly acceding countries shall, by 31 March of each year, and for the first time by 31 March 2007, report to the Commission on the progress made in addressing each of the benchmarks provided for (Article 1). The decisions also foresee the communication of the Commission's comments on the respective reports to the European Parliament and the Council (Article 2).

The benchmarks identified, set forth in the annexes of the respective decisions, are indispensable pre-requisites for the functioning of the predominant integration instrument in the two areas targeted by the safe-

\footnotetext{
63 Lazowski (n 43) 418.

64 See recitals 8 of both Decisions: Commission Decision (2006/929/EC) establishing a mechanism for cooperation and verification of progress in Bulgaria to address specific benchmarks in the areas of judicial reform and the fight against corruption and organised crime [2006] OJ L354/58 ; Commission Decision (2006/928/EC) establishing a mechanism for cooperation and verification of progress in Romania to address specific benchmarks in the areas of judicial reform and the fight against corruption [2006] OJ L354/57.

65 Ibid, recital 6 of the respective Commission Decisions.

66 This provision provides that the institutions of the Union may before accession adopt the measures referred to in, inter alia, Articles 37, 38 and 39 of the Protocol concerning the conditions and arrangements for admission of the Republic of Bulgaria and Romania to the European Union.
} 
guard clauses, namely the principle of mutual recognition. Indeed, before listing the respective benchmarks, the Commission recalls the effects of Articles 37 and 38 of the Act of Accession, which include the suspension of [current] Member States' obligation to recognise and execute, under the conditions laid down in Community law, Bulgarian/Romanian judgments and judicial [and prosecutors'] decisions, such as European arrest warrants, ${ }^{\prime} 7$ 'falling under the principle of mutual recognition. ${ }^{68}$ For both Bulgaria $^{69}$ and Romania ${ }^{70}$, the overriding themes of the benchmarks are independence, accountability, transparency and efficiency of the judicial system, connected to and with further insistence on the fight against corruption. Failure to address the benchmarks may result in recourse to the safeguard clause. Arguably, the Commission intended to reinforce the safeguard clauses for these crucial issues by adding a somewhat low-key way of exercising its surveillance over reforms regarding administrative and judicial structures.

67 Recital 7 of the respective Commission Decisions (n 64).

68 European Commission (n 62) 10.

69 Benchmarks to be addressed by Bulgaria are:

1. Adopt constitutional amendments removing any ambiguity regarding the independence and accountability of the judicial system.

2. Ensure a more transparent and efficient judicial process by adopting and implementing a new judicial system act and the new civil procedure code. Report on the impact of these new laws and of the penal and administrative procedure codes, notably on the pre-trial phase.

3. Continue the reform of the judiciary in order to enhance professionalism, accountability and efficiency. Evaluate the impact of this reform and publish the results annually.

4. Conduct and report on professional, non-partisan investigations into allegations of highlevel corruption. Report on internal inspections of public institutions and on the publication of assets of high-level officials.

5. Take further measures to prevent and fight corruption, in particular at the borders and within local government.

6. Implement a strategy to fight organised crime, focussing on serious crime, money laundering as well as on the systematic confiscation of assets of criminals. Report on new and ongoing investigations, indictments and convictions in these areas.

70 Benchmarks to be addressed by Romania are:

1. Ensure a more transparent, and efficient judicial process notably by enhancing the capacity and accountability of the Superior Council of Magistracy. Report and monitor the impact of the new civil and penal procedures codes.

2. Establish, as foreseen, an integrity agency with responsibilities for verifying assets, incompatibilities and potential conflicts of interest, and for issuing mandatory decisions on the basis of which dissuasive sanctions can be taken.

3. Building on progress already made, continue to conduct professional, non-partisan investigations into allegations of high-level corruption.

4. Take further measures to prevent and fight against corruption, in particular within the local government. 


\section{Benchmarking, post-accession conditionality and their impact on compliance mechanisms}

Post-accession conditionality mechanisms and their underlying rationale of protecting the achieved level of integration, leading on from the instruments of prescribing, monitoring, assessing and guiding in the pre-accession context, invite a more general reflection on EU compliance mechanisms. Maintaining the momentum of European integration, ultimately rests upon compliance with the acquis, understood as encompassing adoption, implementation and effective enforcement, enabled by the Member States' adequate administrative and judicial structures. Indeed, implementation and enforcement issues have steadily drifted up the EU political agenda, and one reason for this arguably lies in enlargement, ${ }^{71}$ generating an intrinsic link between the growing emphasis on effective implementation and enforcement, as well as the imperative of adequate administrative and judicial structures, and the difficulties in general of ensuring compliance with EU law. In this context, it can be argued that enlargement provided an opportunity, as well as the experiences in carrying out the pre-accession strategies and expertise,

to experiment with new methods for securing compliance that complement the EU's existing sanctions-based mechanisms in a way that is more reflective of this notion of voluntary cooperation. The introduction of such methods in the relationship between the EU and the present Member States may serve to enhance patterns of compliance in those states as well. ${ }^{72}$

The following reflections on compliance with the acquis communautaire, understood in the broad sense usual in the enlargement context, ${ }^{73}$ in a post-accession period, will follow a two-fold approach which reflects the following distinction with respect to the Commission's steadily increasing powers: direct expansion of the Commission's powers due to the processes and procedures of the pre- and post-accession conditionality strategies, inferable from the wording of the safeguard mechanisms in particular; and indirect expansion by way of what the wording of the provisions leaves out. ${ }^{74}$ Before doing so, a few preliminary remarks are required.

71 Cf C Harlow and R Rawlings, 'Accountability and law enforcement: the centralised EU infringement procedure' (2006) 31 ELR 447, 452.

72 R Bieber and M Vaerini, 'Implementation and Compliance: Stimulus for New Governance Structures in the Accession Countries' in Bermann and Pistor, Law and Governance in an enlarged European Union (Hart Publishing, Oregon 2006) 389.

73 Cf Delcourt (n 22) 832.

74 However, the distinction thus made between direct and indirect empowerment of the Commission is not a clear-cut one nor does it neatly correspond to other distinctions made with respect to compliance enforcement mechanisms, such as the one advocated by Munoz 
The first point to be mentioned, although strictly speaking limited to the Community legal order, is the principle that ultimately it is the role of the institutions, in particular the Commission and the Court of Justice, to ensure that the law is observed. There is no room, therefore, for any form of 'self-help' compliance enforcement by one Member State in respect of another: direct State-to-State retaliation or counter-measures by another Member State, are not permitted. ${ }^{75}$ Member States have also good cause to delegate the responsibility of law enforcement to the Commission. Interpolation of the Commission between Member States serves to deflect their wrath and defuse inter-state battles at the political level. ${ }^{76}$ At the basis of all compliance procedures lies thus the principle of loyal cooperation enshrined in Article 10 ECT that applies to European institutions $^{77}$ and national authorities alike.

In general however, and this is the second point, the Member States are left to decide for themselves how to implement and bring their law in line with Community law. ${ }^{78}$ In a similar vein, they enjoy autonomy to ensure enforcement of the acquis. The Court of Justice, by invoking Article 10 ECT, has consistently held that in the absence of Community rules governing a matter, it is for the domestic legal systems of each $\mathrm{Mem}$ ber State to designate the courts and tribunals as well as to establish the procedural rules ensuring the protection of individual Community

(R Munoz, 'The monitoring of the application of Community law: a need to improve the current tools and an obligation to innovate' (2006) Jean Monnet Working Paper 04) between ex-ante mechanisms (eg under the Notification Directive), ex-post mechanisms (eg the centralised infringement procedure) and hybrid forms (eg SOLVIT) or the distinction advanced by Bieber (Bieber and Vaerini (n 72) 389) between coercive means (denoting those requirements of EC legislation which restrict the Member States' autonomy in implementing EC law, and whose respect is ensured by the infringement procedure) and soft means (encompassing all EC law measures designed to encourage or facilitate national implementation of EU law and policy, or to guide Member States effectively through the implementation process).

75 The Court of Justice has even held that a failure on the part of one Member State to implement Community regulatory procedures does not justify other Member States in the imposition of health or welfare-based trade restrictions: A Member State may not unilaterally adopt, on its own authority, corrective or protective measures designed to obviate any breach by another Member State of rules of Community law. Case C-5/94 R. v MAFF Ex p. Hedley Lomas [1996] ECR I-2553 para 20, citing Joined Cases 90/63 and 91/63 Commission v Luxembourg and Belgium [1964] ECR 625 and Case 232/78 Commission v France [1979] ECR 2729 para 9. It is however possible of course, although rare, for one Member State to bring an action against another for breach of a Community law obligation, by virtue of Art 227 EC.

76 Cf Harlow and Rawlings (n 71) 452.

77 See, for instance, Case C-65/93 European Parliament $v$ Council [1995] ECR I-643 para 23.

78 Retaliatory or safeguard measures, or other trade defence mechanisms such as antidumping or countervailing duties are not a normal part of the Community legal order. 
rights. ${ }^{79}$ For that matter however, the Court also established limits to national autonomy, referred to as the principle of full effectiveness and the principle of non-discrimination or equivalence. ${ }^{80}$

Finally, the distinction between implementation or transposition through domestic legislation and effective enforcement by national administrative and judicial authorities is to be emphasised. Overseeing the latter, is "most problematic for the Commission, which does not have at its disposal recourse to national courts. Nor does the Commission have at its disposal a general inspectorate, nor indeed any general inspectorial function. ${ }^{81}$ Failure to enforce transposed acquis is difficult for the Commission to identify, so that it has to rely on private informants, and it is harder to prove. It almost goes without saying then, that the lack of these tools, in the light of the principle of 'indirect administration' of the Commission, has important repercussions on the Commission's general role as 'guardian of the Treaties'.

\section{Ensuring compliance in the accession context}

What precisely are then the powers of the Commission in ensuring compliance in the accession context? Do they deviate from its powers in a strictly internal context, and do they even go beyond its constitutional role as 'guardian of the Treaties'? One may begin with and briefly present the Commission's role in the pre-accession and negotiation phase. Indeed, the Commission's role in determining the precise content of the accession conditions, primarily the Copenhagen criteria, has been and continues to be determinative. In procedural terms, the Agenda 2000 methodology of regular monitoring and progress assessment essentially contributed towards enabling the Union to make the criteria not just a 'wish-list' or a statement of expectations, but a workable tool in governing the accession. ${ }^{82}$ By virtue of this methodology, ${ }^{83}$ the Commission exer-

79 See, for instance, Case 33/76 Rewe-Zentralfinanz eG and Rewe-Zentral AG $v$ Landwirtschaftskammer für das Saarland [1976] ECR 1989 and Case 158/80 Rewe-Handelsgesellschaft Nord mbH $v$ Hauptzollamt Kiel [1981] ECR 1805, cited in P Craig and G de Burca, EU Law - Text, Cases, and Materials ( ${ }^{\text {rd }}$ Edition OUP, Oxford 003) $231 \mathrm{ff.}$

80 C-431/93 Van Schijndel [1995] ECR I-4705 para 17; Case C-177/88 Dekker v Stichting voor Jong Volwassenen Plus [1990] ECR I-3941; for further references, see Craig and de Burca (n 79) 234ff.

81 C Harlow, Accountability in the European Union (OUP, Oxford 2002) 72. See also Harlow and Rawlings (n 71) 453. Although it can, in some instances, be empowered to appoint socalled 'authorised agents' to carry out controls and inspections of the Communities' own resources. Council Regulation 1026/1999/EC, cited in Bieber and Vaerini (n 72) 389.

82 Cf Kochenov (n 18) 6.

83 Cf Inglis (n 7) 248. Inglis makes a general point and refers to it as a 'direct consequence of the Union's eagerness to diffuse the potential political fall out of such a rigorous and demanding conditionality' and considers 'the firm grip of the European Commission on the 
cised the complete assessment of compliance with the established conditions through regular reports on progress towards accession ${ }^{84}$, accompanied by analytical papers. ${ }^{85}$ Eventually, today, the Commission manages the entire process of accession. Two instruments in particular deserve special mention, that is the Accession Partnerships (equivalent to the European Partnerships for the countries of the Stabilisation and Accession Process) and the so-called Action Plans. The Accession Partnerships, endorsed by the 1997 Luxembourg European Council as a 'new instrument and a key-feature of the enhanced pre-accession strategy', as well as the comparable European Partnerships, ${ }^{86}$ made the Copenhagen criteria legally enforceable, ${ }^{87}$ since the reception by the candidates of financial aid from the Union was made dependent on their performance related to meeting the Copenhagen criteria. ${ }^{88}$ The individual partnerships, tailor-made and supposedly directed specifically towards each candidate's needs in its preparation for membership, are essentially an oeuvre of the Commission, drawn up, regularly adapted and monitored by its services. The power to sanction the candidate country on the basis of the partnership - via a reduction or suspension of pre-accession funds geared to help its accession - while it is negotiating with the Member States, renders accession negotiations ever more illusionary. This ' $m$ is sous tutelle'89 was

administration of the instruments of pre-accession' as a means that take 'the heat out of the implementation and progress of the pre-accession strategy' and 'bringing structure to the accession negotiations'.

84 From 1998 to 2003, then only on Bulgaria, Romania and Turkey. The 2003 Comprehensive Monitoring Reports on Preparations for Membership by Each of the ten new Member States, released on 5 November 2003, were summarised in a 2003 Comprehensive Monitoring Report and were structurally different from the Regular Reports as they were based acquis chapters. European Commission, '2003 Comprehensive Monitoring Report of the European Commission on the State of Preparedness for EU Membership of the Czech Republic, Estonia, Cyprus, Latvia, Lithuania, Hungary, Malta, Poland, Slovenia and Slovakia' COM(2003) 675 final, 5 November 2003

85 Entitled Composite Papers in 1998 and 1999 and Strategy Papers from then on.

86 These were set up with Albania, Bosnia and Herzegovina, the former Yugoslav Republic of Macedonia, and Serbia and Montenegro including Kosovo and represent a framework of priority action and a financial structure. It is to be noted that not all of these countries had or have contractual bilateral relations at the moment of their adoption. Council Regulation (EC) 533/2004 of 22 March 2004 on the establishment of European partnerships in the framework of the stabilisation and association process [2004] OJ L86.

87 Cf K Inglis, 'The Europe Agreements compared in the light of their pre-accession reorientation' (2000) 37 CML Rev; for a detailed analysis of the Accession Partnerships, see H Grabbe, 'A Partnership for Accession? The Implications of EU Conditionality for the Central and East European Applicants', Working Paper No 99/12 (EUI Robert Schumann Centre for Advanced Studies, 1999).

88 By virtue of Article 4 of Council Regulation (EC) 622/98 on assistance to the applicant States in the framework of the pre-accession strategy, and in particular on the establishment of Accession Partnerships, [1998] OJ L85.

89 Hillion (n 14) 418. 
consolidated by the Action Plans. ${ }^{90}$ Thereby, the candidates were in particular asked to prepare their administrative and judicial structures for accession under close scrutiny of the Commission. In this context, and while the very nature of enlargement necessitates an integrated, cross-pillar approach, requiring the candidate and acceding states not only to align with Community law in a narrow sense, but with the accession acquis in a broad sense including all measures and principles adopted under the second and third pillar, the role of the Commission with respect to conditionality in the Area of Freedom, Security and Justice deserves particular attention. Also in this policy area, it promotes and controls the progressive alignment of the acquis by the future Member States, thereby acting well beyond its traditional role as guardian of the (Community) Treaties vis-àvis the Member States. ${ }^{91}$ On the other hand, giving such responsibilities to the Commission takes the political heat out of managing and checking compliance with what is a highly political area of the acquis.

Worth mentioning also, as they mitigate the impression of the purely technocratic nature of the Commission's role - which admittedly is also the argument for the Commission's central role in the entire process - are the so-called early warning letters. For the first time, in the context of the accession of the ' 10 new Member States', these 'early warning letters at a political level' had been sent to certain candidate states, aimed at putting additional reformatory pressure on candidates in sensitive areas. Interestingly, these were officially signed by the Director General of the Directorate-General for Enlargement at that time, Eneko Landaburu, addressed to the heads of state or government. ${ }^{92}$

Under this comprehensive system, the evolution of the relationship with each candidate, even if ultimately under the political control of the (European) Council was essentially determined on an evaluation and assessment under the sole responsibility of the European Commission. The same is true as to the pace of accession negotiations. Indeed, the pivotal role of the Commission throughout the accession negotiations has already been noted ${ }^{93}$ - one might even argue that the Commission is de facto negotiating the content and limits to the transitional arrangements. This central role has yet again been reinforced by the system

\footnotetext{
90 Ibid

91 For details, see R Byrne, G Noll and J Vedsted, New Asylum Countries? Migration Control and Refugee Protection in an Enlarged European Union (Kluwer, 2002); mentioned also in M Cremona and C Hillion, 'L'Union fait la force? Potential and Limitations of the European Neighbourhood Policy as an Integrated EU Foreign and Security Policy' (2006) EUI Working Papers 39.

92 There was, for instance, a letter sent to the Polish prime minister on the issue of administrative capacity with respect to the administration of agricultural and regional funds.

93 Cf Inglis (n 42) 954.
} 
of 'benchmarking' for the opening and closure of accession negotiation acquis chapters.

Turning to the provisions of the Acts of Accession themselves, one might first mention the Commission's considerable discretion in the interpretation of the general economic safeguard clauses as evidenced by the Court of Justice. ${ }^{94}$ To a similar extent, the wording of the specific safeguard mechanisms in the 2003 and 2005 Acts of Accession has given a "considerable' ${ }^{95}$ discretion to the Commission at all stages of its invocation. The Commission, by 'taking appropriate measures', evaluates whether the commitments have been met or not; it is also the Commission that decides on the necessity of a transitional suspension of the acquis or any other type of action ${ }^{96}$ and - upon their adoption - on their intensity and duration. And again, it is the Commission that may adapt them in the course of time and evaluates whether and when the failed commitments have been remedied to the extent necessary in order to lift the safeguard measures.

Arguably, the conditions of substance imposed on the Commission by these provisions are for the most part merely a codification of principles guiding internal market law and policy in general, or in fact of common sense and proportionality. The Internal Market safeguards clauses provide that 'measures shall be proportional and priority shall be given to measures, which least disturb the functioning of the internal market and, where appropriate, to the application of the existing sectoral safeguard mechanisms' as well as that they 'shall not be invoked as a means of arbitrary discrimination or a disguised restriction on trade between Member States'. The clauses relating to the Area of Freedom, Security and Justice foresee that 'these measures may take the form of temporary suspension of the application of relevant provisions and decisions in the relations between a new Member State and any other Member State or Member States, without prejudice to the continuation of close judicial cooperation' and that they 'shall be maintained no longer than strictly necessary, and, in any case, will be lifted when the shortcomings are remedied.' Ultimately, the Commission's margin of discretion in authorising and determining the appropriate measures depends on the European Court of Justice's appreciation of the level of control required or justified. ${ }^{97}$ Presumably the margin of discretion would be considered as wide

94 Case 11/82 SA Piraiki-Patraiki and others $v$ Commission [1985] ECR 207. Case 258/81 Metallurgiki Halyps $v$ Commission [1982] ECR 4261; Case 289/83 GAARM v Commission [1984] ECR 4295; Case 114/83 Société d'Initiatives et de Coopération Agricole and Société Interprofessionnelle des Producteurs et Expéditeurs de Fruits, Légumes, Bulbes et Fleurs d'Ille-et-Vilaine v Commission [1984] ECR 2589. Cited in Inglis (n 42) 952.

95 Inglis (n 42) 955.

96 Ibid, 'unspecified'.

97 Hillion argues that the European Court of Justice may review the proportionality of the measures adopted by virtue of Article 230 ECT. Cf Hillion (n 42) 602. 
as it is for the general economic safeguard clause. Thus, the applicant under Article 230 ECT will have to show that the measure is 'manifestly inappropriate having regard to the objective which the competent authority wishes to pursue'. ${ }^{98}$ The difficulty of such an undertaking and the political courage required on the part of the new Member State concerned, ${ }^{99}$ is however beyond doubt.

In relation to the Commission's margin of discretion in taking appropriate measures in general, it has been argued ${ }^{100}$ that the expression 'may' suggests one which resembles the discretion the Commission enjoys in relation to infringement proceedings. There, the Commission cannot be sued for having failed to take action, or for refusing to take action. ${ }^{101}$ While in itself arguably not threatening the inter-institutional balance, this discretion does put the Commission in an 'unusual' ${ }^{102}$ and indeed awkward position, as it has been given more teeth to ensure the proper functioning of the internal market vis-à-vis certain Member States than with regard to others.

On the other hand, if one considers that post-accession conditionality is the very raison d'être of the specific safeguard clauses, then this 'highly asymmetrical arrangement' ${ }^{103}$ which distinguishes between the remedies available to the old Member States and those available to the new Member States, is not only justified but also perfectly fits in with the Commission's pivotal role throughout the accession process. The difficulties for the Commission in relation to the burden of proof that a fortiori, as presented above, arise in case of a failure of domestic enforcement, have certainly been a determinative factor for establishing in addition to the 'tools applicable to all Member States', and 'tools based on the Accession Treaty', the cooperation and verification mechanisms. They undoubtedly provides a much more incremental and targeted mechanism to exercise pressure on the judicial systems and the ongoing reforms thereof, on which the Commission's role as 'guardian of the Treaties' inter alia depends. Furthermore, bearing in mind the 'almost unconstitutional' role of the Commission with respect to the Union acquis under Title VI the related screening of national legislation, its prioritisation and the surveillance of its implementation - it does not come as a surprise that this role has been transmitted into the post-accession phase. The absence of temporary derogations, except in relation to the Schengen acquis, led the

\footnotetext{
98 For instance, Case 11/82 Piraiki-Patraiki [1985] ECR 207 and Case C-331/88 Fedesa [1990] ECR I-4023.

99 The two specific safeguard clauses can only be invoked against a new Member State.

100 Cf Hillion (n 42) 604.

101 Case 7/68 Commission v Italy [1986] ECR 423; Case 24/87 Starfruit [1989] ECR 291.

102 Hillion (n 42) 604.

103 Ibid.
} 
Commission and the Member States to envisage 'sui generis' ${ }^{104}$ provisions to address not only the 'serious shortcomings or any imminent risks of such shortcomings in the transposition, state of implementation, or the application of directives and Regulations relating to mutual recognition in civil matters under Title IV of the EC Treaty'. These provisions indeed introduced a fall-back provision that endowed the Commission with the power to suspend the judicial co-operation as a result of alleged 'serious shortcomings or any imminent risks of such shortcomings in the transposition, state of implementation, or the application of the framework decisions or any other relevant commitments, instruments of cooperation and decisions relating to mutual recognition in the area of criminal law under Title VI of the EU Treaty. ${ }^{105}$ The Acts of Accession thus equally granted the Commission considerable power with respect to secondary measures adopted under the third pillar, whereas it does not have an equivalent power under the EU Treaty itself. Indeed, by way of these provisions, the Commission's pivotal role in formulating, monitoring and assessing progress in reforming and adapting the judicial systems of the candidate states has been prolonged into the period after accession for the new Member States. This 'unprecedented power'106 of the Commission is only insignificantly ${ }^{107}$ mitigated by the fact that unlike the provision for temporary Internal Market safeguard measures, the member states must be consulted before such measures are adopted or before they are adapted, or by the fact that the Commission has to 'inform the Council in good time' before revoking the measures and 'take duly into account any [of its] observations in this respect'.

\section{Ensuring compliance in the enlarged Union}

With respect to the effective implementation and enforcement of EU law in the accession context and beyond, it is submitted that one determinative factor of the Union's 'absorption' or 'integration capacity' clearly relates to the imperative of 'full administrative and judicial capacity' of all Member States, and that effective national administrative and judicial structures constitute the basis for the functioning of the Community/ Union legal order in view of maintaining the momentum of European integration'. Indeed, in the light of an increasing emphasis on administrative and judicial capacity of aspiring member states and concerns about

\footnotetext{
104 European Commission (n 55).

105 Articles 39 and 38 of the 2003 and 2005 Acts of Accession, respectively.

106 Cf Hillion (n 42) 607.

107 Hillion in fact turns the argument of the limited ex-ante control of the Member States around, and would envisage the European Court of Justice's jurisdiction with respect to safeguard measures dealing specifically with Title VI TEU considering the power of the European Commission. Ibid 606.
} 
the lack thereof, ${ }^{108}$ it is arguably not a coincidence that the two areas in which the 2003 and 2005 Acts of Accession introduce specific safeguard mechanisms, are also the domains in which mutual recognition is the cornerstone of integration: the Internal Market and the Area of Freedom, Security and Justice. And while the Commission in 2002 declares full administrative and judicial capacity to be in general an 'essential requirement for creating mutual trust among Member States, indispensable for membership, ${ }^{109}$ it is particularly pertinent in these areas.

A few lines on mutual recognition are thus appropriate. The scope for action in establishing and ensuring the smooth functioning of the internal market which was offered by the seminal judgment Cassis de Dijon in the late 1970's was used to replace an early radical approach to market integration with a more mature approach far more respectful of national regulatory autonomy, ${ }^{110}$ and ultimately for national diversity. ${ }^{111}$ In this policy domain, mutual recognition was officially recognised and identified as the basic principle of the legal system of the Community. ${ }^{112}$ In the area of Freedom, Security and Justice, emphasis on mutual recognition in the Third pillar started in Tampere in 1999 where it was stated that it should become the cornerstone of judicial co-operation in criminal matters ${ }^{113}$ and was reiterated in the Hague Programme. ${ }^{14}$ Important

108 Unsurprisingly, large parts of the Community pre-accession assistance have been programmed since the early 1990 s to help candidates in their efforts to build and reinforce their administrative and judicial structures, and particular Action Plans (while this was not the case for other domains) drawn up in order to give new impetus to the candidates' efforts. For an alternative proposal, which is not based on the so-called M\&M solution (money and men), see Nicolaides (n 30) 43.

109 European Commission (n 55).

110 Cf JHH Weiler, 'Mutual Recognition, Functional Equivalence and Harmonization in the Evolution of the European Common Market and the WTO' in F Kostoris and T Padoa Schioppa (eds), The Principle of Mutual Recognition in the European Integration Process (Palgrave, London 2005).

111 In the internal market, this in essence principle is the acceptance on the part of each Member State of any product which has been lawfully produced and marketed in another Member State, even if according to different technical or quality standards, in so far as it meet the legitimate objective which the legislation is designed to achieve. Cf A Mattera, 'The Principle of Mutual Recognition and Respect for National, Regional and Local Identities and Traditions' in F Kostoris and T Padoa Schioppa (n 110).

112 Case C- 184/96 Commission v France (Foie gras) [1998] ECR I-6197.

113 The original idea of applying this principle in the field of criminal law was put forward by the UK in order to address concerns regarding the slow pace of improvement of judicial cooperation in criminal matters. Cf V Mitsilegas, 'The Constitutional Implications of Mutual Recognition in Criminal Matters in the EU' (2006) 43 CML Rev 1277, 1278.

114 See also European Commission, 'Mutual Recognition of Final Decisions in Criminal Matters' COM (2000) 495 final, 26 July 2000. Among the measures adopted, the European Arrest Warrant, pushed through as 'emergency legislation' is certainly the best known and most contested example. The European Arrest Warrant is a judicial decision issued by a Member State with a view to the arrest and surrender by another Member States of an 
differences not withstanding, ${ }^{115}$ the bottom line of mutual recognition in both internal market and criminal law is similar: one Member State is obliged to recognise an individual national standard, judgment or order adopted by other Member States' respective authorities.

By way of such recognition in individual cases, national enforcement authorities implicitly accept as legitimate the national regulatory, legal and justice system which has produced the judgment or standard in the first place. ${ }^{116}$ Such acceptance, and ultimately the efficient functioning of a single legal area is dependent upon a certain, basic, level of mutual trust among all entities, public and private, operating within this single legal space. This applies a fortiori in the context of measures adopted under the third pillar, where Court orders and judgments may have a substantial impact on fundamental rights and concern guarantees against state intervention. The existence of clear and predictable criminal law principles and their rigorous application are essential to provide legal certainty in a society based on the rule of law. ${ }^{117}$ The fact that a persistently high level of corruption in Bulgaria and Romania has been identified is thus of particular concern.

This intrinsic link between mutual trust and adequate judicial and administrative structures should be seen in the larger context of an acquis which has reached a level of complexity that makes it difficult for current and future Member States alike to formally adopt and implement it, but particularly also to enforce it effectively. It has been argued that the "new challenge of compliance' for the Union arising out of the single market

individual for the purposes of conducting a criminal prosecution or executing a custodial sentence or detention order. It thus abolishes the principle of 'dual criminality' for certain crimes. Council Framework Decision of 13 June 2002 on the European Arrest Warrant and the surrender procedures between Member States, [2002] OJ L190/1.

115 In the internal market total automaticity of recognition is avoided, for instance by a test of functional equality: prior to the actual recognition, national authorities have leeway to assess whether there is a level of functional equivalence between the respective national legal systems. In other words, the Member State of destination is required to accept products and services that satisfy the rules of the Member State of origin only provided that the product or service guarantees a level of protection and meets a legitimate objective equivalent to the one required in the Member State of destination, and the level of protection is 'reasonable and satisfactory' in so far as it complies with the results of scientific research in the sector. The minimum threshold is the one required by the Member State of destination; only Community minimum harmonisation can introduce a common threshold of protection for the legitimate objective being pursued. Cf A Mattera (n 111) 18. Peers argues that particularly when comparing the automaticity of the application of the principle, the analogy between the two domains is false, as while the internal market rules require at least a minimal degree of comparability, the abolition of dual criminality is intended to preclude such a comparability test. Cf S Peers, 'Mutual recognition and criminal law in the European Union: Has the Council got it wrong?' (2004) 41 CML Rev 5, 23.

116 Cf Mitsilegas (n 113) 1281.

117 Ibid 1280. 
programme of the 1990s has required an integration of the administrative mechanisms applied by the Commission and the judicial measures administered by the Court of Justice. ${ }^{18}$ This has been reinforced through the fifth enlargement round. Consequently then, the important concerns about effective compliance through efficient public administrations may merely be considered an expression of a much broader phenomenon at the European Union level, in the sense that the 'new' tools of benchmarking and post-accession conditionality - all of which encapsulate essential compliance concerns - de facto reflect a compliance methodology that is spreading throughout many policy domains.

It is indeed possible to argue that the European Commission has borrowed from accession methodology in its role as 'guardian of the Treaties'. In a 2002 communication, which interestingly was published on the same day as a communication on the institutional architecture, ${ }^{119}$ the Commission puts an important emphasis on improving cooperation between the Commission and the Member States with a view to preventing compliance failures. ${ }^{120}$ Notification requirements and corresponding regular publication of statistics such as the Internal Market scoreboards, ${ }^{121}$ and in particular the Annual Report on monitoring the application of Community law, arguably invoke comparison with the monitoring tools and techniques in the accession context. Indeed, a link is made ${ }^{122}$ by the Commission between accession monitoring and its Annual Reports issued for all Member States, although the latter are essentially a "naming and shaming' exercise, or in the words of the Commission one of 'mutual monitoring'. In a similar vein, interpretative communications on a specific matter of Community primary and secondary law as well as technical advice and training sessions for representatives of national authorities resemble twinning programmes and guidance through detailed prescriptions in Accession Partnerships and Action Plans. Accession methodology is also generally visible in the way the Commission seeks dialogue and establishes communication channels with national implementing authorities and the judiciary. For instance it proposes that the so-called 'package meetings', providing an opportunity to discuss with the competent national authorities all infringements detected or suspected in a

118 Cf F Snyder, 'The Effectiveness of European Community Law: Institutions, Processes, Tools and Techniques' (1993) 56 MLR 19.

119 European Commission, 'For the European Union - Peace, Freedom and Solidarity, Communication on the institutional architecture' COM (2002) 728 final, 11 December 2002.

120 Cf European Commission, 'Better Monitoring of the application of Community law' COM (2002) 725 final, 11 December 2002.

121 The Commission keeps regular scoreboards on the implementation of Directives by Member States, presented by State and by sector that allow for verification directive by directive.

122 Cf European Commission (n 55). 
given sector, could be held at an earlier stage in order to seek early compliance. In addition, the European Commission is increasingly involving itself with the implementation phase of directives. Its transposition guidelines and recommendations on transposition ${ }^{123}$ do, at times, arguably come close to encroaching upon the autonomy of the Member States with respect to the enforcement of Community law already referred to. One may conclude that the Commission increasingly reaches out to the administrative and judicial authorities of the Member States. This is a practice that undoubtedly has gained pace and importance through and throughout the pre-accession strategies.

In the absence of detailed primary law provisions, the Commission 'can use litigation as an element in developing its longer-term strategies'; litigation is but a part of ensuring compliance, 'sometimes inevitable but nevertheless generally a minor part. [...] It is in a position to use litigation in a continuous, proactive as well as reactive way, so as to create counters, lay down conditions, or establish frameworks for negotiation. ${ }^{124}$ Indeed, the Commission's discretion related to infringement proceedings ${ }^{125}$ should be seen in a much larger context, including the choice between soft means to encourage compliance ${ }^{126}$ and 'hard' compliance mechanisms. It is submitted that the Commission's wide discretionary powers are justified in terms of its enforcement function in general and the freedom it needs, for instance in preferring long-term over short-term goals. ${ }^{127}$

In addition, the Article 226 ECT compliance mechanism is, especially in the enlarged Union, not without shortcomings - in particular with respect to number and length of proceedings (both administrative and judicial). To begin with, the Commission has - expressly in view of enlargement - in its 'institutional architecture' communication ${ }^{128}$ acknowledged a need for its compliance tools to be considerably strengthened. It has proposed that it should be given power to take decisions itself on

123 Cf European Commission, 'Recommendation on the transposition into national law of Directives affecting the internal market' [2005] OJ L98.

124 Snyder (n 118) 30-31, footnotes omitted.

125 The Commission has discretion within the first administrative stage, for example to negotiate a compliance schedule, and also as to whether or not to bring the case before the Court of Justice, ie initiate the second and judicial phase, in case a Member State does not comply in time with a reasoned opinion. The Court of Justice has held that the Commission is not obliged to act within a specified period [...]. The Commission is thus entitled to decide, in its discretion, on what date it may be appropriate to bring an action and it is not for the Court to review the exercise of that discretion.' Case C-422/92 Commission v Germany [1995] ECR I-1097 paras 16 and 18.

126 Cf Bieber and Vaerini (n 72) 401.

127 Cf Harlow (n 80) 73.

128 European Commission (n 119). 
Union law infringements, in order to be provided with a basis for more effective 'direct' compliance checks in the Member States, and thus with a de facto investigatory function. Secondly, the question has to be asked to what extent the Commission is authorised to set up a selectivity policy in the treatment of infringement procedures. Does its discretion go as far as implementing a 'generalised' filter for certain types of complaints, and thus to 'turning a blind eye' to a certain types of alleged infringements? In the affirmative, on the basis of what criteria could this selectivity be effectuated? Considering the imperative of adequate administrative and judicial structures for the implementation of all Community policies and in particular those based on mutual recognition, would it be possible to find criteria that sufficiently take that into account? Again, the particular difficulty in ensuring domestic enforcement has to be recalled. Clearly such a selectivity policy raises questions that are difficult to tackle, yet alone solve, and in turn underline the importance of informal compliance mechanisms. Accession conditionality instruments largely reflect such informal compliance mechanisms - even if they have become in part legally enforceable. Whether these quasi-legal conditionality mechanisms of the pre-accession phase adequately fulfil their role in a strictly postaccession context remains to be seen.

\section{Concluding remarks}

Undoubtedly, the fifth enlargement has changed the 'constitutional fabric $^{129}$ of the European Union. This paper has been an endeavour not only to present the most recent developments in accession conditionality but also to put them in the broader context of the functioning of the enlarged European Union in general, and the latter's system of compliance mechanisms in particular. Thereby, the nature of the specific safeguard clauses in the 2003 and 2005 Acts of Accession as well as of the cooperation and verification mechanisms with respect to Bulgaria and Romania has been revealed as post-accession conditionality tools that invoke comparison with pre-accession conditionality methodology, in particular in terms of empowerment of the European Commission and preference of quasi-formal or quasi-legal monitoring and early compliance tools. The empowerment of the Commission is also an implication of the broad understanding of the notion 'acquis communautaire' in the enlargement context, namely comprising 'the content, principles and political objectives of the Treaties, including those of the Treaty on European Union'. The specific Justice and Home Affairs safeguard mechanisms in particular, have provided the Commission with 'unprecedented power' which is not

129 B De Witte, 'Enlargement and the EU Constitution' in M Cremona (ed), The Enlargement of the European Union (OUP, Oxford 2003). 
only peculiar with respect to the domain, ie police cooperation in criminal matters, but also highly asymmetrical, in applying only to the new Member States.

One might argue that this is in part justified by the inherently integrated nature of the accession process and the efficiency thereof, in particular in order to transpose the remarkable and unprecedented system of 'multi-layered conditionality' 130 into the post-accession phase, on the basis of a rationale which seeks to protect current and future integration objectives. An objective and merits-based use of conditionality enables the European Union to lessen the negative implications of differentiation between the acceding states, but what place should (or should not) it have once accession has taken place? Shouldn't the benefits of membership be unconditional upon compliance with the acquis? After all, the post-accession conditionality mechanisms in concrete terms entail the exclusion of a new Member State and its citizens and economic operators from the benefits of membership in specific areas. Or does the overriding objective of peace and stability in Europe justify increasing differentiation among the Member States? Politically speaking, it would seem untenable to revert to safeguard measures directed against new Member States, if the 'current' Member States were not correctly implementing and fully enforcing the legal measure in question. ${ }^{131}$ Moreover, by taking parallel action against the 'current' Member States itself, the Commission could defuse differentiation or discrimination arguments, which in turn would help to built a 'reputation' for the specific safeguard mechanisms based on what they really are, namely an additional leverage for the Commission to achieve compliance with the acquis and administrative and judicial capacity improvement. Nonetheless, it is not without repercussions when compliance failures increasingly are dealt with by means of informal, administrative enforcement procedures at the expense of judicial enforcement procedures; especially in view of the supplementary purpose of the formal infringement procedure, namely the uniform application of Community law. Informal, soft and other compliance mechanisms certainly fulfil that aim with less authority.

On the other hand, it has also been seen that these various new compliance mechanisms inspired by the accession strategies have sparked a kind of spill-over effect with respect to enforcement procedures within the European Union in general. The fifth enlargement has provided for an opportunity to experiment with new methods for securing compliance, complementary to the traditional infringement proceedings. Thus, the Union's involvement in new Member states' administrative structures

130 Cremona and Hillion (n 91) 8.

131 Cf Inglis (n 42) 957. 
cannot be seen as a limited practice, but rather presages a more fundamental evolution. And while a 'transfer of methodology' might not be defendable in all instances, it can hardly be doubted that the imperative of effective acquis enforcement through efficient and adequate administrative structures has gained momentum in view of the fifth enlargement.

One may ask whether the shift from predominantly positive pre-accession conditionality to a clearly negative post-accession conditionality is desirable. It is submitted that this shift in approach has its basis in the nature of both the accession process and the functioning of negative conditionality. Suffice to recall that while in the pre-accession phase the negative implications of burdensome reforms may be discounted against the aggregate benefits of eventual membership, making positive conditionality an effective tool, the Union no longer has such leverage in the post-accession phase. The considerable delay in necessary reforms in the judicial systems of Bulgaria and Romania illustrate this, with the quasiagreed date of entry for these countries undoubtedly having contributed to the necessity of adopting a cooperation and verification mechanism in this regard. As to the nature and functioning of negative conditionality, the fact that the specific safeguard mechanisms, legally enshrined in primary law, barely have been used ${ }^{132}$ corresponds to the very rare invocation of essential element clauses in international agreements with third states. In the post-accession context too, the value of legally enforceable negative conditionality tools is of a primarily symbolic nature.

Within an 'ever closer Union', the principle of loyal cooperation, enshrined in Article 10 ECT and underpinned by institutional enforcement mechanisms and non-reciprocity, is the legal expression of solidarity and mutual trust, whose continuing presence at all levels is indispensable for maintaining the momentum of European integration. We are certainly justified in wondering then whether this principle is sufficiently strong to ensure cooperation and mutual trust in a post-accession situation where the difficult balance between inclusiveness and differentiation has been carried over from the pre-accession period. Are not the post-accession conditionality tools encroaching upon the essential premise of mutual trust even if their introduction was intended to avoid that? After all, in a 'Community of laws' built on common rules, the achievement of its purpose is - in view of the integration model that Europe has adhered to - dependent on each member's judicial and administrative capacity. One

132 On 27 June 2007, the European Commission presented its report on the progress made by Bulgaria and Romania in meeting the benchmarks, pursuant to Art 2 of Commission Decisions 2006/929/EC and 2006/929/EC (n 64). While criticising the countries in failing to meet the benchmarks, especially those on anti-corruption , the Commission refrained from invoking the safeguard clauses. <www.euobserver.com> accessed 27 June 2007. This paper had to be finalised before the publication of the report itself. 
might wonder then why reflections on the European Union's 'absorption' or 'integration capacity' have - at least from the official side - merely been focused on creating the 'institutional conditions for ensuring the proper functioning of the Union'. This quote from the 1994 Essen European Council indeed is no exception. Referral to the 'absorption capacity' in Presidency Conclusions ${ }^{133}$ has been limited to institutional aspects. But even in this respect, the 'Amsterdam leftovers' in relation to institutional reform were only narrowly been agreed in the Nice Treaty, completing 'the institutional changes necessary for the accession of new Member States'. The latter, while recognising the need for further institutional debate, did not 'guarantee any continued momentum towards integration.' ${ }^{134}$ The positive Irish referendum result in October 2002 then could not - while consolidating the institutional enlargement adaptations - bring an end to the issue of the Union's condition for enlargement - ie its 'integration capacity'. Despite the ongoing procedural and substantial clarification of the conditions for accession as regards aspiring Member States - with the latest and so far most significant step having been introduced in the benchmarking of the opening and closure of acquis accession negotiation chapters - the unpredictability of the accession process will persist in the enlargement condition applicable to the Union itself. And while the empowerment of the European Commission has both been a necessity and a consequence of the multi-faceted pre-accession strategies that paralleled the accession negotiations, it cannot provide sufficient support for attaining 'integration capacity', the Union's enlargement condition, in particular if the latter to a large extent consists of - as has been argued - the effective enforcement of the acquis through full administrative and judicial capacity of all Member States. The recognition that enlargement increasingly changes the Union by affecting its constitutional balance and calling into question its compliance mechanisms, is a sign of necessary reflection on the Union's functioning and the 'integration capacity' condition. The recent Commission communication in this respect ${ }^{135}$ focuses mainly on institutions, common policies and the European Union budget and is thus an insufficient response, although the Commission draws the right conclusions on what is in its competence and capacity to achieve. ${ }^{136}$

\footnotetext{
133 For a detailed account, see G Edwards, 'Reforming the Union's Institutional Framework: A New EU obligation?' in C Hillion (ed), EU Enlargement - A Legal Approach (Hart Publishing, Portland 2004) 23.

134 Ibid 36.

135 Cf European Commission (n 34).

136 It is relatively powerless in addressing the root problem of mutual trust between the Member States.
} 
Eventually it will become essential to address the question of whether the European Union, by extending accession conditionality tools increasingly into the post-accession phase, risks unacceptable differentiation among its Members States, which at some point may no longer be confined to compliance mechanisms. Considering that avoiding new dividing lines in Europe has been the most legitimate aim in the fifth enlargement, in excluding any partial membership or privileged partnership considerations, the alternative, namely expressly offering a different kind of relation- or membership to third states, might then become worth reconsidering, or even preferable for aspiring members. Clearly, the European Union needs to come to terms with the internal effects of its most successful foreign policy so far. For the sake of the effectiveness and uniform application of Community law in those areas that constitute essential parts of European integration today, and thus the integrity of the Community legal order, these reflections constitute an unavoidable imperative in the future. 